Światowa historia literatury polskiej. Interpretacje, pod red. Magdaleny Popiel, Tomasza Bilczewskiego, Stanleya Billa, Wydawnictwo Uniwersytetu Jagiellońskiego, Kraków 2020, stron 677

\title{
Mapowanie kanonu. Literatura polska w perspektywie światowej
}

ABSTRACT. Mikołajczak Małgorzata, Mapowanie kanonu. Literatura polska w perspektywie światowej [Mapping the Canon. Polish Literature in the World Perspective]. „Przestrzenie Teorii” 35. Poznań 2021, Adam Mickiewicz University Press, pp. 395-413. ISSN 1644-6763. DOI 10.14746/pt.2021.35.19.

The article discusses the research proposal presented in Światowa historia literatury polskiej. Interpretacje [World History of Polish Literature. Interpretations], edited by Magdalena Popiel, Tomasz Bilczewski and Stanley Bill. Mikołajczak contrasts the research concept of world literature with the dominant approaches to the world literature in the area of contemporary literary studies and the traditional model of the history of literature. She reflects on the situation of Polish literature in the world, taking into account the ways in which Polish works circulate in other cultural circles, the possibilities and limitations of translation as well as shifts within the canon. She also indicates the opportunities that open up for Polish literature in the global context.

KEYWORDS: world literature, history of Polish literature, intercultural transfer, canon, translation, reception

Wśród „możliwych innych” historii literatury, powstających w odpowiedzi na kryzys syntezy historycznoliterackiej, diagnozowany na początku lat dziewięćdziesiątych przez Teresę Walas ${ }^{1}$, propozycja opracowana przez Magdalenę Popiel, Tomasza Bilczewskiego i Stanleya Billa wyróżnia się co najmniej potrójnie: reprezentuje nowa, obiecująca perspektywę badawcza; oferuje ujęcie bardzo atrakcyjne dla polskiego czytelnika, zwłaszcza dla czytelnika zainteresowanego międzynarodową recepcją rodzimej twórczości oraz - co łączy się z wymienionymi cechami - odpowiada na wyzwanie, jakie przed literaturoznawstwem stawia kultura tranzytywna, sieciowość

${ }^{1}$ Por. T. Walas, Czy jest możliwa inna historia literatury?, Kraków 1993. Najbliższym kontekstem dla omawianej książki są dwie trzy wydane niedawno pozycje: Being Poland. A New History of Polish Literature and Culture since 1918 (red. T. Trojanowska, J. Niżyńska, P. Czapliński, A. Polakowska, Toronto 2018) i A. Nasiłowska, Historia literatury polskiej (Warszawa 2019), Another Canon.The Polish Nineteenth Novel in World Context (red. G. Borkowska, L. Wiśniewska, Zürich 2020). 
i globalizacja. Wyzwanie streszcza się w pojęciu „literatura światowa” i wiąże się $\mathrm{z}$ tendencja, która od dwóch dekad intensywnie rozwija się w nauce o literaturze, a w ostatnich latach przenika również do polskiej refleksji badawczej $^{2}$, u nas jednak nie zaowocowała jak dotąd pracami o charakterze historycznoliterackim. Dlatego Światowa historia literatury polskiej. Interpretacje (Kraków 2020) ma szczególną rangę: jest nie tylko pierwszą rodzima monografią poświęconą literaturze światowej, ale też pierwszą publikacja adaptująca kategorię world literature do badań nad twórczościa polską.

Sam koncept „literatury światowej” nie jest nowy. Już w roku 1827 na łamach czasopisma „Über Kunst Und Altertum” terminem Weltliteratur posłużył się Goethe, postulując koncepcję „literatury powszechnej [Weltliteratur] dla całej ludzkości”, a przedtem jeszcze pojęcie to było wykorzystywane przez innych autorów, m.in. Augusta Ludwiga Schlözera ${ }^{3}$.

Idea historii literatury, która byłaby alternatywna wobec narodowego monolitycznego modelu i obejmowałaby różnorodność rozmaitych literatur, odżywa dziś w obszarze badań interkulturowych, uprawianych pod hasłami „międzynarodowej historii literatury”, „transkulturowej historii literatury” i „porównawczej literatury światowej”. Wywiedzione stąd projekty badawcze wyznaczaja horyzont współczesnej komparatystyki kulturowej ${ }^{4}$ - najbardziej wpływowe spośród nich to „Światowa Republika Literatury” Pascale Casanovy, „literatura światowa” Davida Damroscha i „światowy system literatury" Franco Morettiego ${ }^{5}$.

Redaktorzy monografii, czerpiąc z tych inspiracji - głównie z rozważań Damroscha, który definiuje literaturę światowa ,jako dzieła czytane poza krajem rodzimym i poza gronem odbiorców specjalizujących się w literaturze danego kraju” ${ }^{6}$ - przyjmuja własną perspektywę, zorientowaną na

${ }^{2} \mathrm{Na}$ temat literatury światowej pisali u nas m.in. Andrzej Hejmej - w kontekście komparatystyki (Komparatystyka i (inna) historia literatury, [w:] Kulturowa historia literatury, pod red. A. Łebkowskiej, W. Boleckiego, Warszawa 2015, s. 83-104) i Tomasz Bilczewski w kontekście przekładu (Historia literatury, komparatystyka, przekład, [w:] Kulturowa historia literatury..., s. 105-114), sześć lat temu ukazał się numer „Tekstów Drugich” (2014, nr 4) w całości poświęcony literaturze światowej.

${ }^{3}$ Por. F. Rosset, Czy „Rękopis znaleziony w Saragossie” Jana Potockiego jest utworem polskim?, [w:] Światowa historia literatury polskiej. Interpretacje, pod red. M. Popiel, T. Bilczewskiego, S. Billa, Kraków 2020, s. 141. Wszystkie kolejne cytaty, pochodzące z tej książki, będę oznaczać skrótem ŚHLP i numerem strony.

${ }^{4}$ Por. A. Hejmej, dz. cyt., s. 89.

${ }^{5}$ Por. P. Casanova, Światowa republika literatury, przeł. A. Turczyn, E. Gałuszka, Kraków 2017; D. Damrosch, What is World Literature?, Princeton-Oxford 2003; F. Moretti, La letteratura vista da lontano, Torino 2005.

${ }^{6}$ D. Damrosch, Literatura światowa $w$ dobie postkanonicznej i hiperkanonicznej, przeł. A. Tenczyńska, [w:] Niewspótmierność. Perspektywy wspótczesnej komparatystyki. Antologia, pod red. T. Bilczewskiego, Kraków 2010, s. 373. 
zagraniczne funkcjonowanie rodzimej twórczości. Interesuje ich światowa historia literatury polskiej, czyli taka, która pokazuje, jak za sprawą przekładu polskie teksty wychodza poza obręb jednego języka i uczestniczą w wielojęzycznym i zarazem wielokulturowym obiegu. Projekt ma charakter światowy również z tego względu, że - jak czytamy we wstępie - „wynika z próby wyjścia poza granice oglądu uwarunkowanego wyłącznie lokalnie poprzez oddanie głosu przedstawicielom różnych języków, geografii i wspólnot wyobrażonych" (ŚHLP 14).

Przedstawicieli, o których tu mowa, jest trzydziestu trzech. Każdy z nich jest związany (za sprawą pochodzenia bądź zatrudnienia na zagranicznej uczelni) z kultura inną niż polska, każdemu (oprócz Normana Daviesa, autora posłowia) powierzono opracowanie jednego rozdziału poświęconego wybranemu autorowi oraz jego dziełu. Owe wybory bynajmniej nie są oczywiste. Stanowia, jak wyjaśniaja redaktorzy, efekt negocjacji z autorami, a równocześnie wynikaja z formuły całości - i nad nią na początek trzeba się zatrzymać.

Obszerny, bo liczący ponad sześćset siedemdziesiąt stron, tom światowej historii literatury polskiej zaczyna się od rozdziału na temat Bogurodzicy (poprzedza go Wprowadzenie. Literatura polska i jej światy), a kończy się rozdziałem poświęconym Księgom Jakubowym Olgi Tokarczuk (właściwym zamknięciem tomu jest wyżej wspomniane posłowie). Pomiędzy nimi mieszczą się omówienia utworów należących do kolejnych epok, przy czym reprezentacja poszczególnych okresów jest nieproporcjonalna: literaturze staropolskiej i oświeceniu poświęcono po cztery rozdziały, po trzy romantyzmowi i dwudziestoleciu, po dwa przypadły na pozytywizm i Młodą Polskę, najwięcej, bo aż trzynaście rozdziałów zajmuje literatura współczesna.

Chronologia to jedyna zasada łączacca to opracowanie z tradycyjną syntezą historycznoliteracka, pozostałe parametry Światowej historii literatury polskiej sa niestandardowe, co w pierwszym rzędzie wiąże się z multifokalizacja: literatura jest tu ukazana w szerokim spektrum wynikającym $\mathrm{z}$ wielu punktów widzenia, a zarazem w zbliżeniu, perspektywę oglądu wyznacza z jednej strony różnorodność kulturowa (autorzy poszczególnych rozdziałów reprezentują szesnaście kultur pochodzących z czterech różnych kontynentów) i wielość języków badawczych, z drugiej - ukierunkowanie na poszczególne dzieło i jego autora. Dzięki mikroskopowemu oglądowi (sygnalizowanemu w podtytule książki: Interpretacje) utwór nie jest jedynie „okazem, reprezentującym pewną historyczną klasę dzieł”, ale - o co przed laty dopominał się Janusz Sławiński, pisząc o syntezie historycznoliterackiej - realnościa, która „sama przez się zasługuje na uwagę”. Formuła

${ }^{7}$ J. Sławiński, Historio literatury - badaj się sama, „Teksty” 1976, nr 2, s. 4. 
historycznoliteracka, która zaproponowali redaktorzy tomu, mogłaby być odpowiedzią na ówczesne dylematy Sławińskiego, który pytał:

Czy zatem trzeba bezwzględnie pogodzić się z tym dramatycznym rozdarciem literaturoznawczego dyskursu? Albo historia literatury, albo „sztuka interpretacji”? Albo strategia badawcza programowo zrywająca więzi z praktyką czytania, albo strategia wchodzaca w aktywny dialog z ową praktyką - jednak za cenę pozostawania poza granicami wiedzy uchodzacej za naukową? Wyobrażam sobie historię literatury, która usiłowałaby to rozdwojenie przezwyciężyć [... $]^{8}$.

W tym wypadku próbą przezwyciężenia rozdźwięku czy - jak to ujmuje badacz - „rozdarcia” i „rozdwojenia” między podejściem syntetyzujacym i idiograficznym jest rozwiązanie stosowane w nowoczesnych podręcznikach: w tekst główny wpisano ramki informacyjne - kapsuły, zawierające różnego typu hasła. Wśród objaśnień o charakterze słownikowo-encyklopedycznym znalazły się odniesienia szczegółowe (do autorów, utworów, wydarzeń politycznych i historycznych itp.) i ogólne (do zjawisk z zakresu poetyki, procesu historycznoliterackiego, kultury, życia literackiego etc.), które nie tylko wzbogacają kontekst, ale też porządkują wiedzę i urozmaicają przekaz. Dwutorowość narracji profiluje kształt książki - ma ona jednocześnie wymiar naukowy i dydaktyczny, jest adresowana zarówno do znawców literatury, jak i czytelników nieprofesjonalnych, może tė̇ z powodzeniem pełnić rolę przewodnika po literaturze polskiej.

Walor zaproponowanej przez redaktorów historii literatury polega też na tym, że przekuwa w atut słabe punkty tradycyjnej syntezy historycznoliterackiej, o której Henryk Markiewicz pisał swego czasu:

[...] skądkolwiek patrzymy, synteza historycznoliteracka jawi się nam jako konstrukcja ułomna - nie dając się w pełni zrealizować ze względu na luki materiałowe, niepewna swego obiektywizmu w doborze i interpretacji dostępnego materiału, zdeformowana, jeśli nie subiektywizmem, to w każdym razie prezentyzmem, tylko hipotetyczna w wyjaśnianiu, zmagajacca się z trudnościami opornej przez swą linearność materii językowej, skazana nieuchronnie na niejednorodność i niekonsekwencję, kompromisy i wybiegi ${ }^{9}$.

Dziś mianem „konstrukcji ułomnej” skłonni bylibyśmy nazywać raczej te opracowania, które wyrastają z utopijnej ambicji ogarnięcia całości i aspiruja do tego, by oferować przegląd pełny, wyczerpujacy, wszechstronny. Ponowoczesne literaturoznawstwo niewątpliwie domaga się nowego podejścia,

${ }^{8}$ Tamże, s. 6.

${ }^{9}$ H. Markiewicz, Dylematy historyka literatury, [w:] Nowe problemy metodologiczne literaturoznawstwa, pod red. H. Markiewicza, J. Sławińskiego, Kraków 1992, s. 22. 
dlatego warto zapytać: czy formuła światowej historii literatury polskiej wraz z cechującymi ją lukami materiałowymi, subiektywizmem w doborze i interpretacji, z kompromisami, niejednorodnością i niekonsekwencjami innymi słowy: z tym wszystkim, co wypunktował Markiewicz - nie jest aby najlepszą możliwą propozycją? Taką w dodatku, która nie wymaga dodatkowych uzasadnień, gdyż w sukurs przychodzi tu sposób konceptualizowania literatury światowej. Twórczość tę można bowiem ujmować najogólniej rzecz biorąc na dwa sposoby i badać ją albo tak, jak proponuje autor ,światowego systemu literatury" Moretti, a zatem opisując wzajemne zależności między dziełami, poszukując ogólnych zasad rządzących artystyczną twórczościa i stosując zasadę czytania z dystansu (distant reading), albo - i z tą właśnie opcja mamy tutaj do czynienia - tak jak chce Damrosch: preferując close reading oraz „tryb czytania, którego można doświadczyć intensywnie z kilkoma dziełami równie efektywnie, co w przypadku badania ekstensywnego z dużą ich liczbą"10. W tym drugim wypadku wyzwaniem staje się dobór lektur i jego kryteria.

Co zatem wybrano? Z tekstów kluczowych dla polskiej literatury w Światowej historii literatury polskiej znalazły się tylko niektóre: wspomniana wyżej Bogurodzica, która jako najstarszy utwór napisany w języku polskim ma niekwestionowany status tekstu „pierwszego”, a także pieśń Czego chcesz od nas, Panie i Treny Jana Kochanowskiego, Sonety Mikołaja Sępa Szarzyńskiego, Mikołaja Doświadczyńskiego przypadki Ignacego Krasickiego, Pan Tadeusz Adama Mickiewicza, Lalka Bolesława Prusa, Quo vadis Henryka Sienkiewicza, zbiór Łaka Bolesława Leśmiana, Granica Zofii Nałkowskiej, Trans-Atlantyk Witolda Gombrowicza, Inny świat Gustawa Herlinga-Grudzińskiego, Pamiętnik z powstania warszawskiego Mirona Białoszewskiego, Prosze państwa do gazu Tadeusza Borowskiego. Ponadto przedmiotem interpretacji stały się wybrane utwory „kanonizowanych" twórców: wiersze Do Matki Polki i Polaty się tzy... Mickiewicza, Ironia Cypriana Norwida, Który skrzywdziłeś Czesława Miłosza, Pisanie życiorysu Wisławy Szymborskiej, Spróbuj opiewać okaleczony świat Adama Zagajewskiego, nowela Wiosna Brunona Schulza, dramat Białe matżenstwo Tadeusza Różewicza, cykl reportaży Podróże z Herodotem Ryszarda Kapuścińskiego. A dalej: utwory, które sytuują się raczej na obrzeżach głównego korpusu klasyki literatury polskiej, takie jak Rękopis znaleziony w Saragossie Jana Potockiego, Nienasycenie Stanisława Ignacego Witkiewicza, Płomienie Stanisława Brzozowskiego, Solaris Stanisława Lema, „rosyjski” cykl Mariusza Wilka, Myśli nieuczesane Stanisława Jerzego Leca. Wreszcie teksty, które - wolno przypuszczać - nie zmieściłyby się nawet w kanonie

${ }^{10}$ D. Damrosch, Dość czasu i świata, przeł. A.F. Kola, „Teksty Drugie” 2014, nr 4, s. 123. 
sensu largo: Duma Lukierdy Franciszka Karpińskiego, Lejbe i Siora Juliana Ursyna Niemcewicza, Palę Paryż Brunona Jasieńskiego. Powyższy zestaw skłania do pytań w rodzaju: dlaczego omawiany jest dramat Różewicza, a nie jego poezja? co zdecydowało, że wśród licznych wierszy noblistki wyróżniono Pisanie życiorysu? a jeśli uwzględniono pozostałych noblistów, to czemu nie ma Władysława Reymonta? Można by się upominać również o innych autorów, zwłaszcza o „wielkich nieobecnych”: co z Juliuszem Słowackim? Krzysztofem Kamilem Baczyńskim? Zbigniewem Herbertem? innymi?

Wszystkie te pytania należałoby jednak uchylić; wyrastaja one z przywiązania do tradycyjnego pojęcia kanonu, a czy dzisiaj istnieje jeszcze jakiś kanon? Żyjemy w epoce postkanonicznej, twierdzi Damrosch i trudno nie zgodzić się z tym rozpoznaniem. Nawet więc jeśli „intensywne czytanie” obejmuje nie „kilka”, lecz ponad trzydzieści utworów, jak dzieje się to w omawianej książce, to nie można oczekiwać, że będzie to podręcznikowa reprezentacja.

Demontaż kanonu ściśle się wiąże z sytuacja, w jakiej znajduje się literatura światowa, podlegająca wielokierunkowym obiegom, transferom, przepływom. Z jednej strony mamy do czynienia ze „zmienną liczbę zagranicznych dzieł, aktywnie cyrkulujacca wewnątrz danej kultury"11, tj. z mikrokanonem, z drugiej - z mapowaniem tradycyjnego kanonu i przewartościowaniem, wynikającym tyleż z ,zainteresowań i preferencji obecnych w środowisku literackim" (ŚHLP 18), co z geokulturowych dyslokacji. Literatura polska, funkcjonująca w wielojęzycznej transnarodowej przestrzeni, byłaby zatem - posłużę się charakterystyką kanonu transatlantyckiego Bożeny Shallcross - nie „skróconą lub uproszczoną wersja polskiego kanonu, lecz jego adaptacja - przy pomocy przekładów - w innym języku i systemie edukacyjnym, innej kulturze, dzięki innym podmiotom” 12 ; „zmieniającą się konstelacją"13, która dzięki tłumaczom i badaczom ulega ciąłemu przeorientowaniu. Dlatego pytanie o wybór bezpośrednio łączy się z najważniejsza dla literatury światowej kwestia, jaka jest przekład.

W przypadku światowej historii literatury polskiej, napisanej przez przedstawicieli zagranicznych ośrodków, wykładowca i tłumacz to nierzadko ta sama osoba. Można przypuszczać, że część omawianych utworów znalazła się tu właśnie ze względu na translację dokonaną w ostatnim czasie. Dotyczy to m.in. Lalki, którą na grunt japoński adaptował w roku 2017 Tokimasa Sekiguchi, Granicy przetłumaczonej na język angielski w roku 2016 przez Ursulę Phillips, rosyjskich tłumaczeń prozy Wilka, którymi od roku 2001 zajmuje się Irina Adelgejm (ostatnie tłumaczenie ukazało się w roku 2017)

11 Tamże, s. 22.

${ }^{12}$ B. Shallcross, Requiem dla kanonu? Szczególny przypadek kanonu transatlantyckiego, przeł. A. Skrabińska-Zielińska, „Teksty Drugie” 2014, nr 4, s. 292.

${ }^{13}$ Tamże. 
czy - biorąc pod uwagę przekład, który ukazał się już jakiś czas temu - pieśni Czego chcesz od nas, Panie przełożonej na język włoski przez Andreę Ceccherelli; tłumaczenia Podróży z Herodotem dokonanego przez Wu Lan, wiersza Opiewaj okaleczony świat, którym zajęła się Clare Cavanagh.

Najnowsze dokonanie translatorskie to przekład Ksiag Jakubowych na język angielski (The Books of Jacob), który ukazał się w listopadzie 2021 roku. Pracy nad tłumaczeniem książki Tokarczuk poświęcony jest ostatni rozdział, mający status odmienny od pozostałych. Redaktorzy nazwali go „codą, uruchamiając kilka znaczeń tego określenia. W świetle wcześniejszego rozdziału, zamkniętego rękopisem wiersza Opiewaj okaleczony świat Zagajewskiego, praca w słowie, z której zdaje relację Jennifer Croft, staje się niejako podjęciem afirmatywnego gestu - przesłanie Zagajewskiego znajduje oddźwięk w mikrosuspensie, jakim jest „pragnienie czytania dalej, żądza przewrócenia kartki” (ŚHLP 631). Odejście poety, który zmarł 21 marca 2021 roku, już po ukazaniu się książki, nieoczekiwanie dopisało do zainscenizowanego w ten sposób dialogu nowy komentarz, wzmacniając brzmienie tego ostatniego akordu.

Twórczość Zagajewskiego od dawna już rezonuje poza strefę lokalna, a jej przykład unaocznia, jak owocna może być współpraca wybitnego poety i znakomitego tłumacza. W dużym stopniu za sprawą Cavanagh Zagajewski należy dziś w Stanach Zjednoczonych do najbardziej znanych polskich autorów i cieszy się tam popularnością znacznie większą niż np. Różewicz ${ }^{14}$. To jeden z paradoksów literatury światowej: zagraniczna recepcja, a dotyczy to nie tylko wymienionych poetów, odbiega, niekiedy znacznie, od rodzimego odbioru. Za tę sytuację najczęściej odpowiedzialny jest tłumacz. Poezja Różewicza, słabo znana w Ameryce, znajduje silniejszy oddźwięk na Wyspach Brytyjskich, gdyż swoja poetycką obecność w języku angielskim poeta zawdzięcza głównie Adamowi Czerniawskiemu, mieszkającemu w Wielkiej Brytanii.

Tłumacz jest promotorem, a często także akuszerem sukcesu autora, czego dowodzi niemal każdy rozdział omawianej książki. Dlatego trudno się dziwić Wu Lan, gdy pisze: „Dziś z prawdziwą dumą i satysfakcją mogę stwierdzić, że dzięki moim przekładom na chiński Ryszard Kapuściński zyskał w Chinach sławę wybitnego reportażysty" (ŚHLP 591). Ale można tu znaleźć także sporo przykładów świadczących o tym, że sam tłumacz nie wystarczy. Na przykład w wypadku dramatów równie dużo zależy od reżysera. Dowodzi tego m.in. amerykańska recepcja Białego matżeństwa, o której pisze Tamara Trojanowska - dzięki udanym realizacjom teatral-

${ }^{14}$ Pisze o tym Piotr Wilczek, Kanon literatury polskiej jako wyzwanie dla zagranicznego polonisty. Problem przekładu, „Wielogłos” 2008, nr 2/4. 
nym ta właśnie sztuka Różewicza jest najbardziej popularna w Ameryce Północnej. Natomiast jeśli chodzi o utwory „do czytania” (niesceniczne), czynnikami, które mają realny wpływ na popularność danego autora, są: znane wydawnictwo, dobra prasa (głównie recenzje w prestiżowych wydawnictwach), rekomendacja literackich autorytetów (pisarzy i krytyków) ${ }^{15}$. Taką opiniotwórczą rolę odegrała swego czasu Historia literatury polskiej Miłosza, stając się punktem odniesienia dla sposobu odbioru literatury polskiej w Stanach Zjednoczonych. Phillips właśnie Miłoszowi przypisuje słabe zainteresowanie tamtejszych czytelników Granica Nałkowskiej. „W swoich ogólnych uwagach zamieszczonych w Historii - stwierdza - przyjmuje on [Miłosz - przyp. M.M.] wobec Nałkowskiej postawę dość pogardliwa, poświęcając jej zaledwie jedną stronę" (ŚHLP 369). Odwrotny przypadek to patronat, jakim wybitni pisarze anglojęzyczni, Philip Roth i Cynthia Ozick, objęli pisarstwo Schulza. Stanley Bill pisze, że w latach siedemdziesiatych i osiemdziesiątych ubiegłego stulecia to właśnie ich opinie stanowiły siłę napędową rozwoju reputacji polskiego pisarza i sprawiły, że zaczęto go postrzegać jako „tajemniczy talent, który wyłonił się z prowincjonalnego mroku »innej Europy«, zanim został połknięty przez wojenną zagładę” (ŚHLP 380). Zaskoczeniem dla polskiego czytelnika może być uznanie, jakim pisarza z Drohobycza darzą tak znani twórcy, jak John Updike czy Maxwell Coetzee.

Najbardziej jednak frapujący, jeśli chodzi o losy recepcji, okazuje się... przypadek. Może on wpłynąć na przekład na wiele sposobów, tak choćby jak stało się to z wierszem Zagajewskiego, błędnie przetłumaczonym z powodu uszkodzonego faksu. Lektura Światowej historii literatury polskiej jest niezwykle ciekawa również z tego względu, że unaocznia, jak często dynamiką odbioru rządzi nieoczekiwane wydarzenie, splot okoliczności. Gdyby Albert Camus nie zginął w wypadku, to entuzjastycznie przez niego przyjęty Inny świat Herlinga-Grudzińskiego znalazłby we Francji wydawcę już w latach sześćdziesiątych. Stało się inaczej i książka polskiego autora ukazała się tam dopiero w roku 1985. W międzyczasie we Francji zmieniły się nastroje polityczno-społeczne, a wraz z nimi oczekiwania czytelnicze i zaraz po ogłoszeniu publikacji pojawiły się wypowiedzi, z których, jak odnotowuje Maria Delaperriére, „przebija uczucie zażenowania, że dzieło tej rangi co Inny świat musiało czekać na francuskie wydanie aż trzydzieści pięć lat" (ŚHLP 426). To zresztą nie koniec zaskoczeń, kolejnym jest to, że francuskie tłumaczenie powieści zostało oparte na wersji... angielskiej.

W świetle tych i innych przytoczonych w książce historii sentencja $\mathrm{Ha}$ bent sua fata libelli nabiera nowego znaczenia. Każdy rozdział Światowej historii literatury polskiej staje się osobną fascynującą opowieścią o książ-

${ }_{15}$ Tamże. 
kach, które przekroczywszy granice macierzystego języka, otrzymują nowe życie, przechodzą metamorfozę. Niekiedy zmieniają się nie do poznania, jak stało się to z powieścią Płomienie, przełożoną na język niemiecki przez Stanisława Kubickiego. Tłumacz posłużył się utworem Brzozowskiego dla własnych celów politycznych, dlatego powycinał niektóre fragmenty, zlekceważył walory estetyczne i z ambitnego dzieła uczynił rodzaj powieści przygodowej. Trzeba było dopiero kolejnego przekładu autorstwa Leona Richtera, by obudzić zainteresowanie Ptomieniami jako utworem przełamującym granice gatunku, nowatorskim. Odwrotny efekt osiagną anonimowy tłumacz powieści epistolarnej Lejbe i Siora, który również mocno ingerował $\mathrm{w}$ tekst oryginału, manipulujacc nim w celach politycznych i społecznych. Aby wpisać utwór w program emancypacji ludności żydowskiej, umiędzynarodowił jego przesłanie i zrezygnował z polskich kontekstów. Dzięki temu „żydowski romans” Niemcewicza, który w kraju spotkał się ze słabym odzewem, został żywo przyjęty i równie żywo dyskutowany przez ówczesnych holenderskich czytelników.

Z perspektywy literatury światowej tradycyjny dylemat dotyczący przekładu, który wyraża się w alternatywie „wierny czy piękny?”, okazuje się nie tak istotny, ważniejsza jest polityka przekładu i pole napięć między tożsamością i różnica, władzą i przyporządkowaniem. Jak pisze Knut Andreas Grimastad:

Każdy przekład jest interpretacją i formą wymiany kulturowej, osadzonej i uwikłanej w strukturach władzy oraz dyskursach tożsamości, nieustannie negocjujacych między przeszłością a teraźniejszościa, lokalnym a globalnym, podobieństwem a różnica, udomowieniem a wyobcowaniem (ŚHLP 442).

Główne pytanie, które przewija się przez całą książkę, brzmi zatem inaczej: czy zachować kulturę oryginału, czy „przystosować” tłumaczenie do kultury docelowej? Kluczowe okazują się tu dwie strategie przekładu sformułowane przez Lawrence'a Venutiego: wyobcowanie, które zakłada, że język docelowy powinien dostosować się do znaczeń tekstu źródłowego (source-oriented) i udomowienie, polegajace na ruchu odwrotnym, tj. na przybliżeniu tłumaczonego tekstu do odbiorcy (target-oriented). Utwór Niemcewicza dzięki udomowieniu otrzymał niejako „drugie życie”, ale autorzy omawianej ksiażki pokazują też, jak utwory mogą stracić na przełamywaniu polskiej formy. Dotyczy to m.in. opowiadań oświęcimskich Borowskiego, przetłumaczonych na język angielski. Ruch poza to, co narodowe, a także w kierunku uniwersalizacji znaczeń, wymusił rozwiąania, które spowodowały, że utwory Borowskiego odbierano w kategoriach świadectwa, a ich autora traktowano jako ocalała ofiarę, pomijając artystyczno-literacki wymiar jego relacji. Nie 
udało się pokazać, pisze Bożena Karwowska, że Borowski za pomocą języka uzyskał to, „co dopiero czterdzieści lat później w filozoficznym eseju zawarł Primo Levi, mówiąc o braku poczucia wspólnoty więźniów, jej przyczynach i konsekwencjach świadka" (ŚHLP 409).

Rozstrzygnięcia dotyczące przekładu to bez wątpienia jeden z ważniejszych problemów literatury światowej. Dzięki autorom, którzy uchylają tajniki swego warsztatu translatorskiego, książka daje wgląd w stosowane przez nich praktyki „udomowienia”, pozwala zobaczyć, jak to wygląda „od środka”. Oryginalne rozwiązanie zastosował Sekiguchi, tłumacząc na język japoński Lalkę: aby rozróżnić odmiany polszczyzny, którymi posługują się poszczególni bohaterowie powieści, przypisał niektórym z nich inny rodzaj pisma i zastosował... katakanę, tj. sylabariusz używany w Japonii głównie do zapisu zapożyczeń oraz nazw własnych obcego pochodzenia. W przypadku powieści Prusa wyzwaniem dla tłumacza stała się różnorodność typologiczna postaci, wymagająca korzystania z kilkudziesięciu stylów, tonów, języków. Częstszym problemem jest idiomatyczność języka, jednak i ona nie musi być przeszkoda. Wirtuozeria stylistyczna Myśli nieuczesanych Leca, opartych na kalamburach i figurach retorycznych (zeugmie i sylepsie) wydaje się nieprzekładalna, a jednak tłumaczenie na język szwedzki wybranych aforyzmów, które powstało z inicjatywy Leonarda Neugera, okazało się strzałem w dziesiątkę. Szwedzi dostrzegli i docenili maestrię i błyskotliwość Leca, jego grę z totalitaryzmem, dowcip. Stylistyczne straty zostały zrekompensowane „wejściem w głąb”, „zwiększeniem zasięgu” - na tym właśnie, tłumaczy Damrosch, polega proces stawania się literatura światowa, czyli taka, jak głosi jedna z trzech definicyjnych tez badacza, która zyskuje w tłumaczeniu ${ }^{16}$.

W ostatecznym bilansie zysków i strat, traktowanych za Robertem Frostem jako to, co gubi się w przekładzie, szala zdecydowanie przechyla się na korzyść tych pierwszych. A w takim razie należałoby zapytać, co oprócz wejścia w obieg światowy, zyskuje literatura polska? Lektura książki, opracowanej przez Popiel, Bilczewskiego i Billa, pokazuje, że zysków jest wiele. Najważniejszy z nich to osadzenie polskich utworów w nowych kontekstach i wywiedzione stąd nowe odczytania. Tak na przykład powieść Mikołaja Doświadczyńskiego przypadki, interpretowana w nawiązaniu do osiemnastowiecznej filozofii Kanta i w perspektywie europejskiego oświecenia, okazuje się dziełem, które oddaje „skomplikowane napięcia między Wschodem a Zachodem Europy” i ugruntowuje „wizerunek Polski jako po-

${ }^{16}$ D. Damrosch, Dość czasu..., s. 101. Dwie pozostałe tezy brzmią następująco: „Literatura światowa to eliptyczna refrakcja literatur narodowych” i „Literatura światowa to nie ustalony kanon tekstów, lecz tryb lektury: forma bezstronnego zaangażowania w światy poza naszym własnym miejscem i czasem" (s. 101). 
mostu między oboma biegunami europejskiej kultury" (ŚHLP 105). Innym przykładem świeżego spojrzenia jest zestawienie Bogurodzicy z Pochwała stworzenia św. Franciszka z Asyżu, od której rozpoczyna się historia literatury włoskiej. To sąsiedztwo odsłania tyleż analogie, co różnice, niemniej rozważania na temat „zagadkowego palimpsestu”, które przy tej okazji snuje Ranocchi, rzucają na Bogurodzicę nowe światło. Ponadto dowodza, że nowa komparatystyka to jedna z tych dziedzin, które dają odpowiedź pozytywna na pytanie postawione jakiś czas temu przez Marcina Cieńskiego: „czy literatura dawna jest dziś jeszcze czytana, czytelna i potrzebna"17. Potwierdzenie przynosi również lektura rozdziałów, w których badacze z zagranicy czytają inne polskie utwory sprzed wieków: Treny i pieśń Czego chcesz od nas Panie Kochanowskiego, Sonety Sępa Szarzyńskiego, utwory Karpińskiego, Potockiego, Niemcewicza.

Kontekst światowy pozwala wydobyć niedostrzegalne, a często też niedoceniane, jeśli patrzeć na nie jedynie z polskiej perspektywy, walory rodzimego pisarstwa. Na przykład dla Francuzów Inny świat stanowi jedno z najważniejszych dzieł, pozwalających poznać i przeniknać mechanizmy sowieckiego systemu; dla Amerykanów „polska szkoła poezji”, której znaczenie wzrosło po ataku na World Trade Center, jest podpowiedzia, jak radzić sobie z traumatycznym doświadczeniem historii; we Włoszech Quo vadis to „bestseller na miarę światową, łączący w sobie elementy powieści psychologicznej, kryminału, thrillera; dla czytelników rosyjskich fikcyjny świat przedstawiony w Solaris to jeden z najsłynniejszych literackich światów alternatywnych, zestawiany z Atlantydą Platona, Utopią Thomasa More'a, Laputa Jonathana Swifta czy zaginionym światem Arthura Conan Doyle'a.

Bywa, że zagraniczna lektura prowadzi do zaskakujacych rewaloryzacji. Ariko Kato, japońska badaczka dopomina się o ponowną ocenę twórczości Brunona Jasieńskiego, przedstawiając autora Pale Paryż jako „utalentowanego twórcę opowieści, który łącząc osobiste historie bohaterów o różnorakim zapleczu społecznym, przekształcił opartą na absurdzie fabułę w fascynująca powieść, którą czyta się jednym tchem" (ŚHLP 325). Zapewne współczesne realia i doświadczenie pandemii stanowią dodatkowy impuls, by przeczytać na nowo powieść Jasieńskiego, ukazująca wieloetniczne, wielokulturowe i wielojęzyczne wymiary metropolii dotkniętej epidemią. A inny powód, który wskazuje Kato, to autorska świadomość kreowania Orientu: „Z dzisiejszej perspektywy - stawia tezę badaczka - Palę Paryż to powieść, która wyprzedza okres pojawienia się problematyki postkolonialnej” (ŚHLP 329). Aktualizacje stanowią dodatkowy efekt zagranicznego oglądu, pozwalaja

${ }^{17}$ M. Cieński, Historia literatury Pierwszej Rzeczypospolitej jako (nieunikniona?) Hybryda. O możliwych nowoczesnych metodach postępowania historyka literatury dawnej, [w:] Kulturowa historia literatury..., s. 126. 
np. w Mikołaju Doświadczyńskim zobaczyć „prototyp polskiego turysty przemierzającego Europę” (ŚHLP 110), w Quo vadis ,zjawisko transmedialne ante litteram, wyprzedzające o niemal stulecie mechanizmy, które dopiero u progu XXI wieku zaczęły rządzić regułami odbioru wszystkich odmian literatury i sztuki" (ŚHLP 278).

Jest wreszcie innego typu profit, który odsłania się, gdy odwracając perspektywę, zapytamy, czy literatura zagraniczna też zawdzięcza coś polskiej twórczości? I tu raz jeszcze przywołam Wu Lan: „Inne kultury to [...] zwierciadła, w których przeglądamy się my i nasza kultura” (ŚHLP 589) powtarza za Kapuścińskim badaczka i wyznaje, że jednym z powodów, które skłoniły ją do rozpoczęcia pracy przekładowej nad Podróżami z Herodotem była ciekawość, jak polski reportażysta postrzega Chińczków. Analogiczna motywacja - zainteresowanie tym, co o Rosjanach myślą cudzoziemcy stanowi o popularności, jaką cieszy się w Rosji cykl północny Wilka. Tego rodzaju konfrontacje są ważne, gdyż pomagają dookreślić własną tożsamość, spojrzeć na siebie „okiem innego”. Ale korzyści jest więcej. „Kultura przyjmująca może użyć obcego materiału na wszelkie możliwe sposoby", pisze Damrosch i wśród owych sposobów wskazuje m.in. wykorzystanie tegoż materiału ,jako pozytywnego modelu dla przyszłego rozwoju własnej tradycji” ${ }^{18}$. Z taką właśnie sytuacją mamy do czynienia w litewskiej recepcji Pana Tadeusza - „żaden inny tekst powstały poza granicami języka litewskiego nie wpisał się w tak znaczacy sposób w kulturę Litwy jak inwokacja Pana Tadeusza" (ŚHLP 197) - zauważa Brigita Speičyté. Badaczka pisze też o tym, że echa inwokacji można usłyszeć także we współczesnej literaturze litewskiej i że inicjalna fraza „Litwo ojczyzno moja” stała się hasłem litewskiego patriotyzmu.

O ile w wypadku wschodniego sasiada intertekstualne zależności nie sa zaskoczeniem, o tyle niespodzianką mogą być ślady lektury polskich dzieł literackich w miejscu odległym geograficznie i kulturowo, jakim jest Brazylia. Chodzi o wiersz Castro Alvesa Do Matki Niewolnika, inspirowany utworem Do matki Polki Mickiewicza i o przekład Polaty się tzy... Paulo Leminskiego. Henryk Siewierski, komentujacc oba te „zdarzenia na planie interkulturowym”, stwierdza, że utwory polskiego wieszcza „pomagaja poezji brazylijskiej kształtować swój własny idiom poprzez transformację i wchłonięcie elementów kulturowo odległych" (ŚHLP 213). Właśnie tego rodzaju oddziaływanie wydaje się stanowić rację bytu literatury światowej.

Są też korzyści niewykorzystane, wynikające z wzajemnego oświetlania się literatury polskiej i zagranicznej i również dzięki tym interferencjom otwiera się pole interesującej relektury. Weźmy Norwida, który „jak gdyby

${ }^{18}$ D. Damrosch, Dość czasu..., s. 104. 
przychodzi z przyszłości, wyrażając poprzez swoje transfery wzniosłości i tragizmu w dziedzinę codziennej pracy prozaiczne tendencje nadchodzącej epoki" (ŚHLP 222). Jego recepcja, zauważa Michał Mrugalski, mogłaby przewartościować postrzeganie niemieckiej tradycji romantycznej, składa on bowiem współczesnym mu poetom ,atrakcyjną ofertę [...] alternatywną wobec głoszonego przez Friedricha [...] od-przedmiotowienia i od-podmiotowienia liryki nowoczesnej" (ŚHLP 224). Nie tylko nowatorska poezja Norwida antycypuje zjawiska pojawiające się w europejskiej literaturze. Prekursorski charakter ma także twórczość Krasickiego i Witkacego. „Gdy Krasicki przeprowadzał elokwentna, acz ostrą krytykę kulturowej opozycji między Wschodem i Zachodem, ówcześni filozofowie dopiero ja wymyślali" (ŚHLP 105) - pisze Shallcross. Z kolei Michał Paweł Markowski twierdzi, że w literaturze europejskiej niewiele jest powieści, które tak jak Nienasycenie, przynoszą spektakularne rozpoznanie sprzeczności, fundujących nowoczesność, dlatego: „Kto chce zrozumieć europejską nowoczesność, powinien koniecznie czytać Witkacego" (ŚHLP 349).

Takie opinie z pewnością cieszą miłośników polskiej twórczości. Czytając Światowa historię literatury polskiej można zresztą znaleźć niejeden powód satysfakcji. Oto na przykład dowiadujemy się, że Wisławę Szymborska cytuje włoska minister pracy, Elsa Fornero oraz największy sportowy dziennik włoski „La Gazzetta Dello Sport”; że w Rosji termin 'solaris', wzięty z powieści Lema, stał się samodzielnym terminem, a sama powieść, ogromnie tam popularna, znalazła się na pięćdziesiątym szóstym miejscu wśród ogłoszonych w roku 2019 „100 Najlepszych Książek Wszechczasów”. Miłym zaskoczeniem może być też „ogromny paradoks”, jak go nazywa Rolf Fieguth, cechujacy niemiecką recepcję polskiej literatury w ostatnich dwóch wiekach. Paradoks polega na tym, że czytelniczej obojętności na polską literaturę w Niemczech towarzyszy ciagłość imponujących dokonań translatorskich: siedem przekładów wierszowanych Pana Tadeusza, trzy przekłady Dziadów, tłumaczenia dzieł wszystkich innych romantyków, cztery wydania utworów zebranych Sienkiewicza, dwie edycje dzieł zebranych Gombrowicza i Mrożka, dwa przekłady opowiadań Schulza. A do tej listy trzeba by jeszcze dopisać innych autorów współczesnych, o których Fieguth nie pisze, np. Herberta, który - to kolejny paradoks - w latach sześćdziesiątych i siedemdziesiątych spotkał się w Niemczech ze znacznie szerszym odzewem (krytycznym i medialnym) niżeli w ojczyźnie ${ }^{19}$.

Jednak ani przytoczone fakty, ani światowa moda na Lalkę czy włoska obsesja na punkcie Quo vadis nie zmienią tego, że literatura polska, trak-

${ }^{19}$ Por. W. Kudyba, Herr Cogito zdobywa przyjaciót. Recepcja Zbigniewa Herberta w niemieckim obszarze językowym, [w:] Herbert Środkowoeuropejczyk. Twórczość Zbigniewa Herberta w kontekstach $i$ kontaktach środkowoeuropejskich, red. K. Krasuski, Katowice 2011, s. 40. 
towana w kategoriach tzw. literatury minor, wciąż pozostaje słabo znana w świecie. I między innymi z tego powodu koncepcja literatury światowej jest dla niej - podobnie jak dla innych mniejszych literatur - bardzo atrakcyjna, daje też szansę na zmianę statusu.

Przypomnijmy, że przez wiele lat na mapie orientowanej według „literackiego południka zero", jakim do połowy XX wieku była stolica Francji ${ }^{20}$, przynależność do „iteratur mniejszych” oznaczała drugorzędność. Konstanty Troczyński ubolewał, że po zrzuceniu przez kraj jarzma zaborów sytuacja naszej literatury w świecie nie wygląda najlepiej i na dowód przytaczał słowa studenta z Paryża:

Trudno się dziwić, że was w Paryżu nie uznaja. Jesteście przecież tylko Francuzami Północy - to, co możecie nam dać, jest późniejszym echem tego, co powstało nad Sekwaną [...]. Nie reprezentujecie dla nas oryginalności. Mnie żywiej obchodzi kultura murzyńska, bo jest ona dla mnie zupełnie obca ${ }^{21}$.

Co jednak stanie się, jeśli zmienimy parametry mapy i zastosujemy większą skalę, uwzględniając także pozaeuropejskie kontynenty? Wówczas sytuacja polskiej twórczości zaczyna być postrzegana inaczej. Efektem rekonfiguracji mapy może być np. spojrzenie na naszą literaturę okiem wschodnich sąiadów, dla których jeszcze w latach sześćdziesiątych XX wieku polska kultura i literatura były głównym „oknem na Europę” i występowały w roli swego rodzaju „implantów kulturowych” (ŚHLP 566), jak określa je Irina Adelgejm.

Przewartościowaniu sprzyja jednak głównie krytyka europocentryzmu dokonująca się pod wpływem teorii postkolonialnych, a także powiązany z tymi teoriami projekt „prowincjonalizowania Europy”. Trzeba pamiętać, że to w dużej mierze dzięki postkolonializmowi nastapiło poszerzenie spektrum badań komparatystycznych i zakwestionowanie utartego podziału na autorów „wielkich” i „pomniejszych”. Zamiast takiego dwupoziomowego modelu i w miejsce kanonu hegemona literatura światowa oferuje nowy system, składający się z trzech poziomów: hiperkanonu, antykanonu $i$ kanonu cieni $i^{22}$. W takim układzie przed twórczościa polska, reprezentująca antykanon, otwierają się nowe możliwości - jej peryferyjne, a jako takie coraz bardziej interesujące, doświadczenie, staje się częścią metropolitalnego obiegu, a jej sposób istnienia w świecie określają nowe współrzędne: transfer międzykulturowy, dynamika rynku przekładowego, globalna sieć wpływów.

${ }^{20}$ P. Czapliński, Literatura światowa i jej figury, „Teksty Drugie” 2014, nr 4, s. 25.

${ }^{21}$ K. Troczyński, Polacy i Murzyni. Uwagi o propagandzie kultury polskiej za granica, [w:] tegoż, Pisma wybrane, t. 2, Kraków 1999, s. 69.

${ }^{22}$ D. Damrosch, Literatura światowa $w$ dobie..., s. 370. 
Trudno sobie wyobrazić literaturę polska, istniejąca w oderwaniu od kontekstu twórczości światowej, „samowystarczalną. Troczyński, który może uchodzić za prekursora prowadzonych u nas dyskusji na temat literatury światowej, dziś już zapewne nie musiałby nikogo przekonywać, że „istnieje nie tylko potrzeba, ale konieczność ułatwiania przez tłumaczenia życia sztuki pod wszystkimi szerokościami i długościami geograficznymi” ${ }^{23}$. W świecie transferów i przepływów, gdy obieg i recepcja dzieł literackich poddane sa nieustannej cyrkulacji i wymianie między lokalnym i globalnym, utwory, tłumaczone na wiele języków, tworzą „światową republikę literatury”. A patrząc na to z innej strony, „Każdy z mieszkańców naszej planety, na której żyje około siedmiu miliardów ludzi, nosi w sobie własna, mniejszą lub większa, literaturę światową” (ŚHLP 243). Ta „Weltliteratur w skali mikro", jak ją określa Sekiguchi, składa się z prywatnych zbiorów należących do czytelników, znajdujących się w różnych częściach świata i tworzy „gigantyczną wirtualną bibliotekę” (ŚHLP 243).

Rozwijając metaforę biblioteki, można stwierdzić, że w światowej historii literatury polskiej chodzi głównie o to, aby umieścić polskie książki w wielu wirtualnych bibliotekach, by wypuścić je w podróż do różnych miejsc świata. Z taką zagraniczną wędrówką łączy się zazwyczaj misja ambasadora rodzimej twórczości. Neuger, który zainicjował tłumaczenie aforyzmów Leca, przyznaje, że zamysł przekładu zrodził się „z uporczywie zadawanego pytania: co z literatury polskiej koniecznie trzeba wprowadzić w obieg literatury światowej?" (ŚHLP 469). Niekiedy na plan pierwszy wysuwa się inne dyplomatyczne zadanie, polegajace na zmianie wizerunku. Katia Vandenborre, komentując cel, jaki postawił przed sobą Marian Pankowski, tłumacz i badacz Łąki Leśmiana, pisze, że:

[...] poprzez wprowadzenie Leśmiana w obręb języka francuskiego połaczone z analizą jego twórczości dążył [Marian Pankowski - przyp. M.M.] do przekształcenia obrazu całej poezji polskiej na Zachodzie, chcac pokazać, że istnieje w jej ramach cały nurt, który nie ogranicza się do roli służebnej wobec narodu (ŚHLP 312).

Ale efekt literatury światowej polega też na tym, że teksty podróżujace za granicę zmieniają się i wracają do nas odmienione. „Te same dzieła powiada Roland Green - wydają się inne, odpowiadają na inne problemy, przemawiaja innymi głosami i posiadają inną wagę, gdy postawić jedno wobec drugiego" ${ }^{24}$. Utwory, które reprezentują równocześnie literaturę polską i światową i które przynależą do transnarodowej przestrzeni literackiej,

${ }^{23}$ K. Troczyński, Samowystarczalność literatury, [w:] tegoż, Pisma wybrane..., s. 66.

${ }^{24}$ R. Green, „Nie dzieła, lecz sieci”: kolonialne światy w komparatystyce, przeł. P. Sobolczyk, [w:] Niewspótmierność..., s. 470. 
nadają kosmopolityzmowi nową jakość. Bierze się ona z dialogu między partykularnym i światowym punktem widzenia; za Damroschem można tu mówić o zjawisku podwójnej refrakcji, które polega na tym, że to, co stanowi narodowy komponent, załamuje się i zmienia w przestrzeni innej kultury, a równocześnie oddziałuje na tę kulturę, poddając ją modyfikacji.

W omawianej książce sprzężenie między światowym i polskim zostaje zaznaczone już na poziomie kompozycji, „narodowe” stanowi bowiem konstrukcyjną ramę odniesienia dla „światowej” opowieści. Książkę otwiera najstarszy hymn polski, zamyka parafraza fragmentu Mazurka Dąbrowskiego przytoczona przez Davisa. Redaktorzy zapewne nie uzgadniali z Davisem treści posłowia, niemniej ta koincydencja jest znacząca, a wzmacniają ja polskie akcenty występujące - bardzo dyskretnie - w szacie graficznej: biel z akcentem czerwieni na okładce, biała i czerwona wstążka, pełniące funkcje zakładki. W tym miejscu trzeba zwrócić uwagę na niezwykle staranna edycję: oprócz rozdziałów właściwych i Cody, na książkę składa się wstęp, posłowie, noty o autorach, spis haseł. Wydanie wzbogacaja dwie reprodukcje - rękopisu Bogurodzicy i rękopiśmiennej wersji wiersza Zagajewskiego, które ujmują część interpretacyjną w klamrę. Dodajmy, że każdy rozdział składa się z podrozdziałów i jest zaopatrzony w bibliografię, a jego poczatek wyróżnia kolorystyka papieru. To oczywiście kwestie, które są wobec zawartości treściowej drugorzędne, niemniej wspominam o nich jako czytelniczka, której podczas lektury tomu towarzyszyła przyjemność nie tylko intelektualna.

Światowa historię literatury polskiej czyta się z niesłabnącym zainteresowaniem. Każdy z jej rozdziałów oferuje osobną opowieść z podwójna, nakładającą się na siebie perspektywą - mikroskopu i lunety. Ta pierwsza uzmysławia między innymi, jaką wagę mają najdrobniejsze translatorskie decyzje, ta druga pozwala śledzić zagraniczne przygody polskich tekstów. Radość czytania rodzi się jednak głównie z odkrywania, że to, co wydawałoby się dobrze znane, wygląda inaczej, a w związku z tym - posłużę się słowami jednego z autorów - „nasze życie jako czytelników nie jest raz na zawsze ustalone i [...] nie musimy aż do śmierci poruszać się zgodnie z utartymi kanonami" (ŚHLP 219).

Nowe trajektorie są zachęta, by wraz z utworami odrywajacymi się od macierzystego kontekstu wyruszyć w „podróż dookoła świata”. Światowa historia literatury polskiej przeciera szlaki tej wędrówki. Opracowana przez literaturoznawców, którzy od lat zajmują się międzynarodową polonistyką (Magdalena Popiel pełni funkcję prezesa Międzynarodowego Stowarzyszenia Studiów Polonistycznych, Tomasz Bilczewski kieruje Katedrą Międzynarodowych Studiów Polonistycznych na Uniwersytecie Jagiellońskim, Stanley 
Bill jest dyrektorem Programu Studiów Polskich na Uniwersytecie w Cambridge), wyznacza przejście od rodzimych dyskusji nad literatura światową do praktyki badawczej i inicjuje nowy kierunek w polskich badaniach historycznoliterackich, a przede wszystkim unaocznia, jak obiecujący jest potencjał światowej historii literatury polskiej.

Parę lat temu Bilczewski, komentując powrót i reinterpretację Goetheańskiej idei Weltliteratur, zapowiadał, że apogeum rozkwitu „literatury światowej" znajduje się dopiero przed nami ${ }^{25}$, a tę opinię formułował w kontekście trzech projektów wydawniczych: książki The Routledge Concise History of World Literature (2012) Theo D'haena oraz prac zbiorowych World Literature. A reader (2013), The Routledge Companion to World Literature (2011). Recenzowany tom pozwala prognozować podobny rozkwit w odniesieniu do światowej historii literatury polskiej. Jej ścieżki rozwojowe projektuje z jednej strony wykaz tych dzieł i autorów, funkcjonujących w światowym obiegu, których tu zabrakło, z drugiej - lista tłumaczy i zagranicznych badaczy literatury polskiej w świecie. Lista ma charakter otwarty. Znakomici autorzy omawianej książki stanowią tylko część międzynarodowej społeczności specjalistów zajmujących się polską twórczością. A trzeba też wziaćc pod uwagę zwiększająca się dynamikę wpływów, przepływów, międzykulturowych transferów, której podlegaja polskie teksty. I jeśli w roku 1933 Troczyński, którego na koniec jeszcze raz przywołam, porównywał polską literaturę do aktora powracajacego na scenę po 125-letnich wakacjach (,Z nielicznymi wyjątkami [...] nikt o nas nic w ogóle nie wiedział, nikt o nas w ogóle wiedzieć nie chciał" - pisał krytyk), to dziś można by w nawiązaniu do teorii Manuela Castellsa ${ }^{26}$ określić tę twórczość mianem aktora sieci, uczestniczacego w procesach wymiany i interakcji o charakterze światowym. Ważnym elementem owego systemu jest zagraniczna sieć ośrodków badawczych zajmujących się polską kultura, literaturą i językiem. Stąd można się spodziewać, że jednym z czynników, które będą stymulować badania nad światową historią literatury polskiej, stanie się zainicjowany parę lat temu projekt geopolonistyki autorstwa Magdaleny Popiel ${ }^{27}$ - jego celem jest zintensyfikowanie międzynarodowej polonistycznej współpracy i wzmocnienie pozycji istniejących Polish Studies. Pointując te rozważania dodam, że Geopolonistyka i światowa historia literatury polskiej to przedsięwzięcia nie tylko sprzęgnięte, ale też bardzo potrzebne - ich efektem jest gęstniejąca mapa polskich śladów w świecie.

${ }^{25}$ T. Bilczewski, dz. cyt., s. 106.

${ }^{26}$ Por. M. Castells, Społeczeństwo sieci, tłum. M. Marody, K. Pawluś, J. Sławiński, Warszawa 2011, s. 435-441.

${ }^{27}$ Por. O geopolonistyce, <https://biuletynpolonistyczny.pl/geoabout/> [dostęp: 24.04.2021]. 


\section{BIBLIOGRAFIA}

Being Poland. A New History of Polish Literature and Culture since 1918, red. T. Trojanowska, J. Niżyńska, P. Czapliński, A. Polakowska, Toronto 2018.

Bilczewski T., Historia literatury, komparatystyka, przektad, [w:] Kulturowa historia literatury, pod red. A. Łebkowskiej, W. Boleckiego, Warszawa 2015.

Casanova P., Światowa republika literatury, przeł. A. Turczyn, E. Gałuszka, Kraków 2017.

Castells M., Społeczeństwo sieci, tłum. M. Marody, K. Pawluś, J. Sławiński, Warszawa 2011.

Cieński M., Historia literatury Pierwszej Rzeczypospolitej jako (nieunikniona?) Hybryda. O możliwych nowoczesnych metodach postepowania historyka literatury dawnej, [w:] Kulturowa historia literatury, pod red. A. Łebkowskiej, W. Boleckiego, Warszawa 2015.

Czapliński P., Literatura światowa i jej figury, „Teksty Drugie” 2014, nr 4.

Damrosch D., Dość czasu i świata, przeł. A.F. Kola, „Teksty Drugie” 2014, nr 4.

Damrosch D., Literatura światowa $w$ dobie postkanonicznej i hiperkanonicznej, przeł. A. Tenczyńska, [w:] Niewspótmierność. Perspektywy wspótczesnej komparatystyki. Antologia, pod red. T. Bilczewskiego, Kraków 2010.

Damrosch D., What is World Literature?, Princeton-Oxford 2003.

Green R., „Nie dzieła, lecz sieci”: kolonialne światy w komparatystyce, przeł. P. Sobolczyk, [w:] Niewspótmierność. Perspektywy wspótczesnej komparatystyki. Antologia, pod red. T. Bilczewskiego, Kraków 2010.

Hejmej A., Komparatystyka i (inna) historia literatury, [w:] Kulturowa historia literatury, pod red. A. Łebkowskiej, W. Boleckiego, Warszawa 2015.

Kudyba W., Herr Cogito zdobywa przyjaciót. Recepcja Zbigniewa Herberta $w$ niemieckim obszarze językowym, [w:] Herbert Środkowoeuropejczyk. Twórczość Zbigniewa Herberta $w$ kontekstach $i$ kontaktach środkowoeuropejskich, red. K. Krasuski, Katowice 2011.

Markiewicz H., Dylematy historyka literatury, [w:] Nowe problemy metodologiczne literaturoznawstwa, pod red. H. Markiewicza, J. Sławińskiego, Kraków 1992.

Moretti F., La letteratura vista da lontano, Torino 2005.

Nasiłowska A., Historia literatury polskiej, Warszawa 2019.

Shallcross B., Requiem dla kanonu? Szczególny przypadek kanonu transatlantyckiego, przeł. A. Skrabińska-Zielińska, „Teksty Drugie” 2014, nr 4.

Sławiński J., Historio literatury - badaj się sama, „Teksty” 1976, nr 2.

Światowa historia literatury polskiej. Interpretacje, pod red. M. Popiel, T. Bilczewskiego, S. Billa, Kraków 2020.

Troczyński K., Polacy i Murzyni. Uwagi o propagandzie kultury polskiej za granica, [w:] tegoż, Pisma wybrane, t. 2, Kraków 1999.

Troczyński K., Samowystarczalność literatury, [w:] tegoż, Pisma wybrane, t. 2, Kraków 1999.

Walas T., Czy jest możliwa inna historia literatury?, Kraków 1993.

Wilczek P., Kanon literatury polskiej jako wyzwanie dla zagranicznego polonisty. Problem przekładu, „Wielogłos” 2008, nr 2/4. 
Małgorzata Mikołajczak - prof. dr hab. Kieruje Zakładem Literaturoznawstwa w Instytucie Filologii Polskiej Uniwersytetu Zielonogórskiego i studiami doktoranckimi w dyscyplinie literaturoznawstwo na Wydziale Humanistycznym Uniwersytetu Zielonogórskiego. Członek Komitetu Nauk o Literaturze PAN i Rady Uczelni UZ. Autorka monografii poświęconych poezji Urszuli Kozioł i Zbigniewa Herberta, a także autorka i współredaktorka monografii dotyczacych literackiego regionalizmu. Redaktor naukowy serii wydawniczych „Nowy regionalizm w badaniach literackich” (TAiWPN „Universitas”) oraz „Historia Literatury Pogranicza” (Oficyna Wydawnicza UZ). Ostatnio opublikowała opracowanie wyboru poezji Zbigniewa Herberta dla Biblioteki Narodowej (Z. Herbert, Wybór poezji, Biblioteka Narodowa, Wrocław 2018). W grudniu 2021 roku ukaże się jej książka poświęcona literackim badaniom regionalistycznym (Ramiona Antajosa. Z teorii $i$ historii regionalizmu literackiego $w$ Polsce). ORCID: 0000-0002-7570-581X. E-mail: <m.mikolajczak@ifp.uz.zgora.pl>.

Małgorzata Mikołajczak - professor, PhD (dr hab.), Head of the Literary Studies Department in the Institute of Polish Philology at the University of Zielona Góra, member of the Committee on Literary Studies at the Polish Academy of Sciences, author of monographs on the poetry of Urszula Kozioł and Zbigniew Herbert. Scientific editor of the "Nowy regionalizm w badaniach literackich" [New Regionalism in Literary Studies] series and "Historia Literatury Pogranicza" [History of Borderland Literature] series. Her research interests include literary theory, contemporary literature and regionalism in literary studies. She has edited the most recent volume of Zbigniew Herbert's poetry Wybór poezji [Selected Poems by Zbigniew Herbert] (Wrocław 2018). December 2021 will see the publication of her latest book Ramiona Antajosa. Z teorii i historii regionalizmu literackiego $w$ Polsce [The Arms of Antaeus. On The Theory and History of Literary Regionalism in Poland]. ORCID: 0000-0002-7570-581X. E-mail: <m.mikolajczak@ifp.uz.zgora.pl>. 
